\title{
23. PARTIAL REORIENTATION OF THE DEFORMATIONAL STRUCTURES AT SITE 735 USING PALEODECLINATION MEASUREMENTS ${ }^{1}$
}

\author{
Mathilde Cannat ${ }^{2}$ and Janet Pariso ${ }^{3}$
}

\begin{abstract}
We propose a reorientation of the deformational structures at Site 735 relative to one another, and to the remanent magnetic vector. This reorientation is based on the assumption that the in-situ stable remanent magnetic vector (SRMV) of each core piece pointed in the same direction before drilling. The consistency of the results supports this assumption. The dominant dip azimuth of the earliest deformation structures (magmatic foliation and some granulite-facies, solid-state foliations) is northwest of the SRMV. These structures tend to make a $45^{\circ}$ angle with the latter solid-state shear zones. The dominant dip azimuth of these shear zones is west of the SRMV, and the stretching lineation is downdip. The true orientation of these structures in the geographic framework is not known because the in-situ azimuth (declination) of the SRMV is still undetermined.
\end{abstract}

\section{INTRODUCTION}

Site 735 lies on a shallow platform on the east wall of the Atlantis II Fracture Zone (Fig. 1). Its position in the magnetic anomaly pattern (Dick et al., this volume) suggests a crustal age of about $11 \mathrm{Ma}$. This is supported by a zircon age of 11.3 Ma (J. Mattinson, pers. comm., 1989).

The $500 \mathrm{~m}$ of gabbros drilled at Site 735 (435 m recovered) comprise metagabbronorites, olivine-bearing and olivine gabbros, $\mathrm{Fe}$-Ti oxide gabbros, and small volumes of troctolites and of evolved late magmatic intrusives (Shipboard Scientific Party, 1989; Fig. 2). About $30 \%$ of these gabbros are plastically deformed (Fig. 2) along flat to moderately dipping normal shear zones (Cannat et al., this volume). Some gabbros are also thought to have been deformed in the magmatic state as a result of viscous laminar flow of the incompletely solidified magma (Cannat, this volume). The synkinematic assemblages in the normal shear zones correspond to metamorphic conditions ranging from granulite to lower amphibolite facies (Stakes et al., this volume). There is no significant ductile deformation in the core below the stability temperature of actinolitic hornblende (Stakes et al., this volume), and brittle deformation is limited. The extensional ductile deformation at Site 735 thus occurred when the gabbros were still hot, probably in the immediate vicinity of the Southwest Indian Ridge (Fig. 1). The fresh gabbros with preserved magmatic textures, and the deformed and metamorphosed gabbros, have identical positive remanent inclinations, suggesting magnetization during a single reversed magnetic interval (Shipboard Scientific Party, 1989). This is another indication of a short time interval between the initial crystallization of the gabbros at the ridge axis and their deformation.

\footnotetext{
${ }^{1}$ Von Herzen, R. P., Robinson, P. T., et al., 1991. Proc. ODP, Sci. Results, 118: College Station, TX (Ocean Drilling Program).

2 GDR “Génése et Evolution des Domaines Océaniques," UBO, 6 av. Le Gorgeu, 29287 Brest Cedex, France.

${ }^{3}$ School of Oceanography, University of Washington, Seattle, WA 98195 , U.S.A.

Note: Although it is assumed in this study that the stable remanent magnetic "ector (SRMV), to which all structural element directions are referenced, has a north azimuth, other studies in this volume (Kikawa and Pariso, Pariso et al.) point out that it is reversed from that of the present field. Therefore, to compare directions in geographic coordinates with other directional data from Site 735, it seems most appropriate to assume that the SRMV points South.
}

The position of the crust at Site 735 relative to the Atlantis II transform valley suggests that its accretion took place some $11 \mathrm{~m} . \mathrm{y}$. ago, about $18 \mathrm{~km}$ to the east of the ridge/transform intersection (Fig. 1). Large-scale normal faulting of the newly created oceanic lithosphere in ridge/transform intersection domains is documented by submersible observations at the Kane Fracture Zone/Mid-Atlantic Ridge intersection (Dick et al., 1981; Karson and Dick, 1984; Mével et al., in press). The extensional ductile shear zones observed in the Site 735 gabbros may be the deep-seated expression of such normal faults (Cannat et al., this volume).

During drilling and coring operations at Site 735, each piece of core was free to rotate around the vertical axis. Only the dip of the deformational structures therefore can be directly measured in the core. Because the stable remanent magnetization of the gabbro section as a whole appears to have been acquired during a single magnetic interval (Shipboard Scientific Party, 1989), the paleomagnetic vector in each piece of core probably pointed in the same direction before drilling. Based on this assumption, the orientation of the deformational structures measured in distinct pieces of core relative to one another, and their trend relative to the paleomagnetic vector, can be reconstructed using the paleomagnetic measurements. This chapter presents the results of this reconstruction. Determination of the azimuth of the deformational structures at Site 735 in the geographic framework involves estimating the in-situ paleomagnetic vector direction, using magnetic logging data (Pariso, unpubl. data). The results presented here show that the shear zones drilled at Site 735 have consistent azimuth and dip directions. This indicates that the tectonic evolution at Site 735 , involving viscous flow of the incompletely solidified magma, followed by solid-state ductile extension at progressively decreasing temperatures, occurred in a coherent strain field. This is also an a posteriori indication that the reorientation procedure adopted here is valid.

\section{REORIENTATION PROCEDURE}

The dip (inclination) and the azimuth (declination) of the stable remanent magnetic vector (SRMV) were measured in 158 samples (Shipboard Scientific Party, 1989; Pariso et al., this volume). Eighty-two of these samples show deformational structures (foliation, lineation, and/or veins), which have been measured using the ODP coordinate system (Fig. 3). The estimated error of these measurements is $\pm 10^{\circ}$. The stable declinations in these 82 samples, measured in the same 


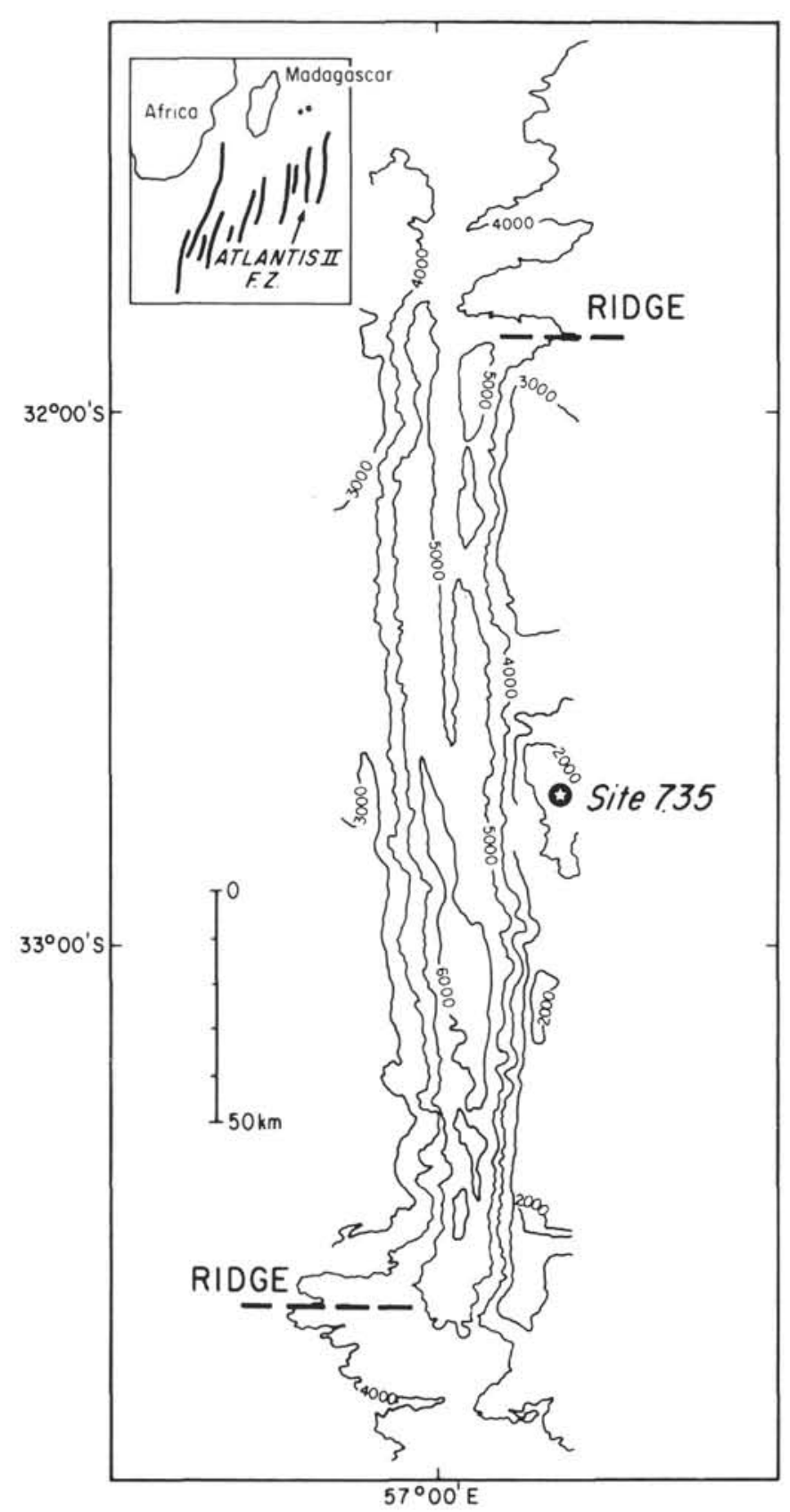

Figure 1. Bathymetric map of the Atlantis II transform fault, showing the location of Site 735. Contour intervals at $1000 \mathrm{~m}$ (survey from Conrad cruise 27-09, 1986; H. Dick, Chief Scientist, with D. Gallo and R. Tyce).

coordinate system, are listed in Table 1 (estimated error: $\pm 15^{\circ}$ ). Our working hypothesis is that the SRMV in all these samples pointed in the same direction before drilling. Because the true orientation of this remanent vector is unknown, it has been set to an arbitrary value of $360^{\circ}$ (north). A correction factor equal to $360^{\circ}$-D (stable remanent declination in the ODP coordinates) was added to the foliation, lineation, and vein directions measured in each sample (Table 1). The resulting corrected values are relative to the direction of the in-situ remanent vector (Fig. 4). When we know the azimuth of this vector relative to geographic north (Pariso, unpubl. data), the

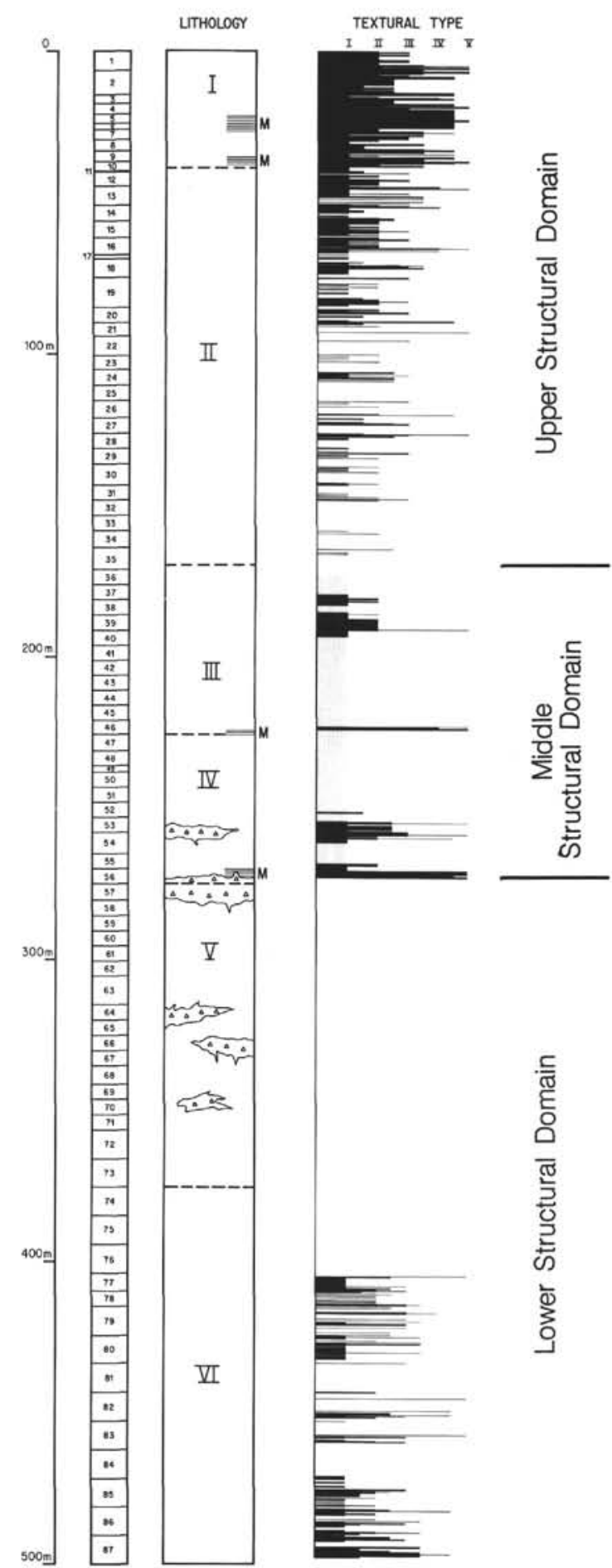

Figure 2. Lithological and structural stratigraphy at Site 735 (Cannat et al., this volume). From left to right: depth below seafloor; core numbers; lithostratigraphy (Unit I: metagabbronorites, and mixed gabbronorite and olivine gabbro; Unit II: olivine gabbro with intervals of oxide gabbro; Unit III: mixed, disseminated oxide olivine gabbro and olivine gabbro with intervals of oxide gabbro; Unit IV: oxide gabbro; Unit V: olivine gabbro; Unit VI: olivine gabbro with troctolites and intervals of oxide gabbro; M.: mylonitic shear zone; small triangles: late magmatic intrusives); textural types, corresponding to increasing finite strain (type I: weakly recrystallized, unfoliated; type II: moderately recrystallized, foliated; type III: extensively recrystallized, well foliated; type IV: extensively recrystallized, with millimeter-thick mylonitic bands; type V: mylonitic). Upper, Middle, and Lower Structural domains: see text. 


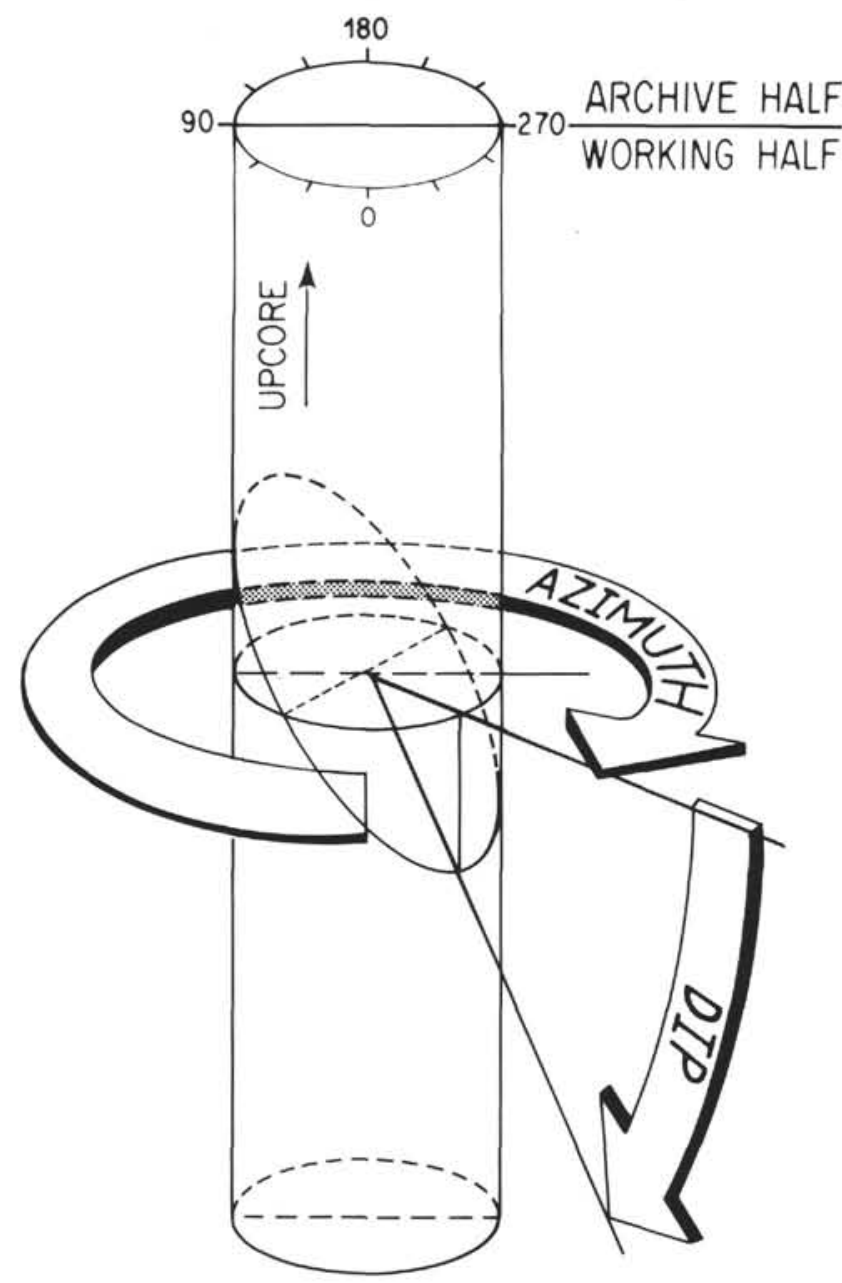

Figure 3. Sketch of the ODP coordinate system, used to measure the azimuth and dip of the deformation structures (foliation, lineation, and veins), and of the stable remanent magnetic vector in each studied sample (see Table 1).

true azimuth of the measured structures can be readily obtained by a simple rotation around the vertical axis.

Cored pieces were cut in half (archive and working halves; Fig. 3) on board the JOIDES Resolution. Foliated pieces were usually cut perpendicular to the foliation. As a result, most uncorrected foliations in Table 1 have a $180^{\circ}$ azimuth in the ODP coordinate system (Fig. 3). The reorientation procedure obviously does not apply to horizontal planar structures. Consequently, the relatively frequent horizontal foliations throughout the hole (Cannat et al., this volume), are not represented in Table 1, nor in the stereoplots of Figure 4. Precise measurements of the lineation azimuth and dip (in the ODP coordinates) are only possible in pieces cut or broken parallel to the foliation plane. This explains the limited number of lineation measurements presented in Table 1. However, the stretching and mineral lineation is near downdip in most deformed samples: the mineral elongation is much stronger in sections cut perpendicular to the foliation and parallel to its downdip direction, than in sections cut perpendicular to the foliation and parallel to its strike.

\section{DOWNHOLE DISTRIBUTION OF THE DEFORMATION AT SITE 735}

The downhole distribution of the ductile deformation in the Site 735 gabbros allows one to distinguish three structural domains (Fig. 2; Cannat et al., this volume):
1. The Upper Structural Domain extends from Core 118735B-1D to Core 118-735B-36R (0-171 m below seafloor [mbsf]). It is characterized by extensive ductile deformation thought to be associated with movements along subhorizontal mylonitic shear zones, located in the lower part of Unit I (Fig. 2; Cannat et al., this volume)

2. The Middle Structural Domain extends from Core 118 735B-36R to the second third of Core 118-735B-56R (171-272 mbsf). It is characterized by the development of a foliation that probably results from laminar viscous flow in the gabbroic magma (Cannat, this volume). This magmatic foliation is overprinted by solid-state ductile deformation in discrete intervals; and

3. The Lower Structural Domain extends from the lower third of Core 118-735B-56R to the bottom of the hole at Core $118-735 \mathrm{~B}-88 \mathrm{~N}(272-500.7 \mathrm{mbsf})$. Only the lower part of this domain (Cores $118-735 \mathrm{~B}-77 \mathrm{R}$ to $88 \mathrm{~N}$; $403-500.7 \mathrm{mbsf}$ ) is plastically deformed.

The solid-state ductile deformation in these three domains occurs in metamorphic conditions ranging from granulite facies to lower amphibolite facies (Stakes et al., this volume). An increase in the ductile strength of the gabbros is inferred to have accompanied this temperature decrease because deformation appears to have occurred at increasing deviatoric stress conditions (Cannat, this volume). In the Upper Structural Domain, shearing at lower temperature (lower amphibolite facies) overprints the higher temperature (granulite and upper amphibolite facies) with the same geometry. In the Middle and Lower Structural domains, the lower-temperature shear zones frequently cut the earlier, higher-temperature, shear zones at a significant angle (Cannat et al., this volume).

The displacements accommodated by brittle failure in the Site 735 gabbros are limited (Cannat et al., this volume). The macroscopic features resulting from brittle deformation in the core are millimeter- to centimeter-thick veins, filled with a variety of hydrothermal minerals (Stakes et al., this volume). These veins are most abundant in the Upper Structural Domain, where they are mostly filled with hornblende and often contemporaneous with the last stages of the ductile deformation (Cannat et al., this volume). In the Middle and Lower Structural domains, the veins are often filled with hydrothermal plagioclase and clinopyroxene and mostly postdate the end of the ductile deformation.

\section{RESULTS}

\section{The Upper Structural Domain}

The declination of the SRMV was measured in 62 samples from the Upper Structural Domain (Shipboard Scientific Party, 1989; Pariso et al., this volume). Forty-two of these samples have been plastically deformed and/or cut by veins filled mostly with green-brown hornblende (Stakes et al., this volume). The stereoplots of Figures $4 \mathrm{~A}$ and $4 \mathrm{~B}$ show the orientation and dip of the foliation, lineation, and veins in these 42 samples (Table 1), relative to the direction of the SRMV $(\mathrm{V}=$ vector $)$.

The mylonitic shear zone at Cores 118-735B-6D (Fig. 2) has a subhorizontal foliation (not represented in Fig. 4A) and a lineation trend of $\mathrm{V} 290^{\circ}$ (Core 118-735B-6D; Fig. 4A). Above and below this shear zone, the foliation's dip azimuth is variable, with roughly three groups of orientations: $\mathrm{V} 0^{\circ}$ to $\mathrm{V} 20^{\circ}, \mathrm{V} 310^{\circ}$, and $\mathrm{V} 200^{\circ}$ to $\mathrm{V} 260^{\circ}$ (Fig. $4 \mathrm{~A}$ ). Conjugate dips, directed toward $\mathrm{V} 130^{\circ}$, were also measured in a few pieces (Fig. 4A). The attitude of the foliation in the Upper Structural Domain is represented schematically in Figure $5 \mathrm{~A}$. The stretching lineation is dominantly downdip in all samples. In 
Table 1. Reorientation data for 82 studied samples, Site 735.

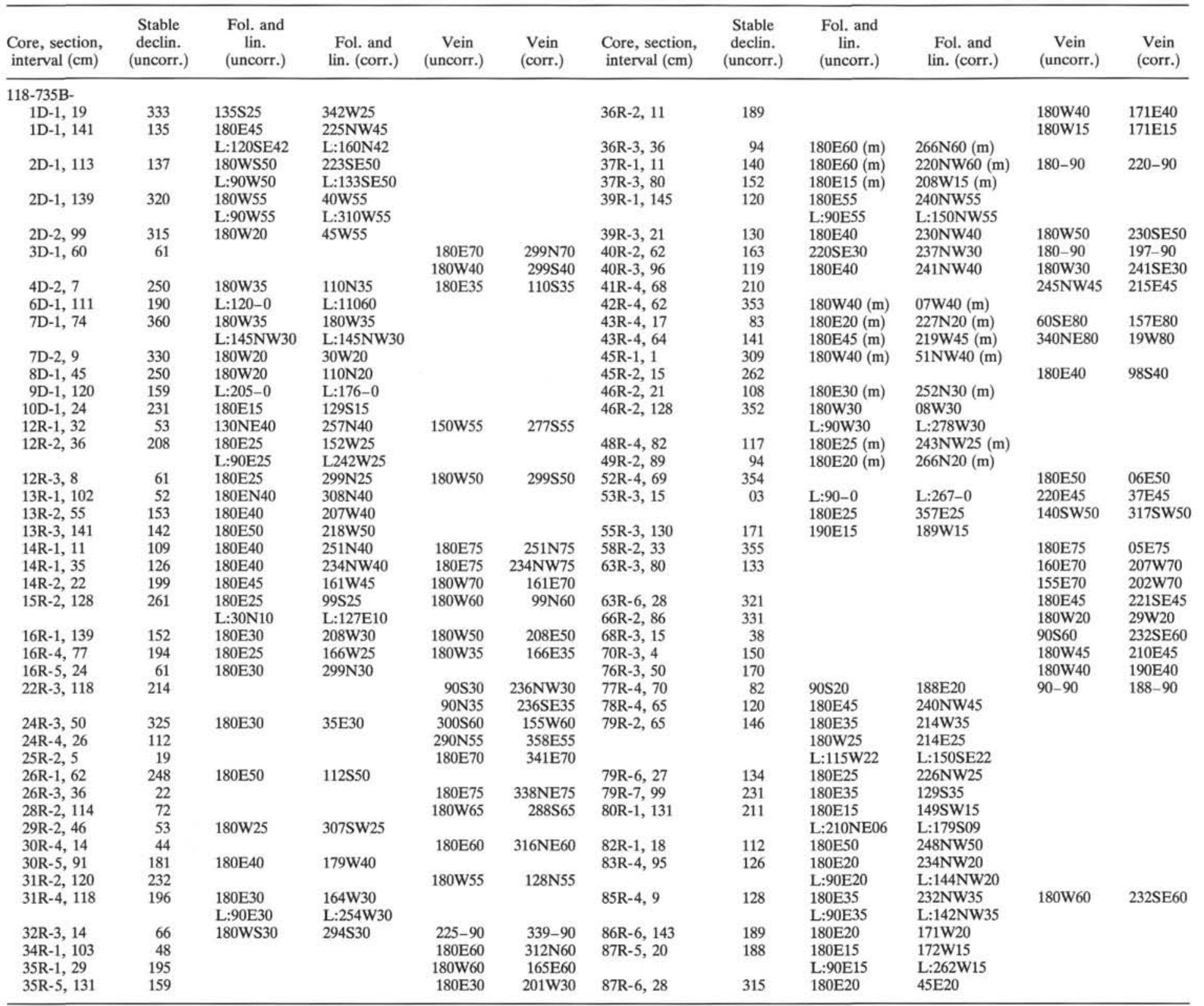

Note: The correction factor is equal to $360^{\circ}-\mathrm{D}$ (uncorrected stable remanent declination). The corrected orientation and dip of the deformation structures are expressed in a coordinate system in which North is parallel to the remanent magnetic vector (see text). 


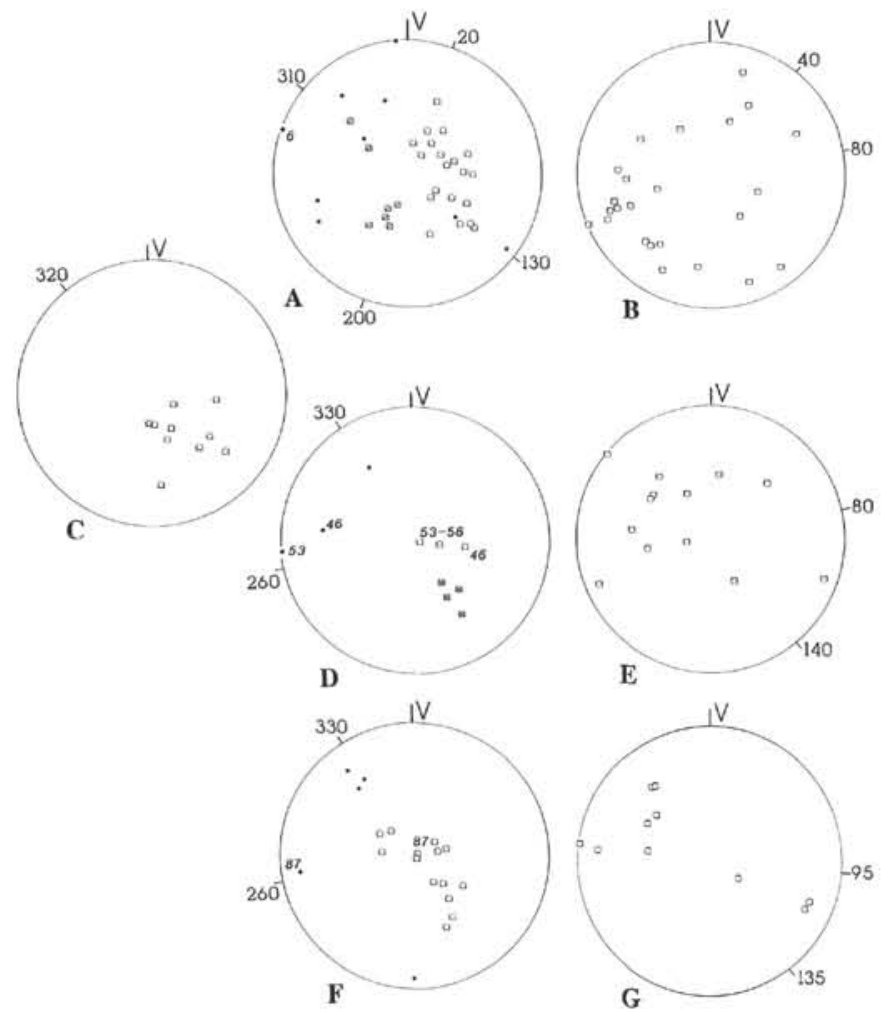

Figure 4. Reconstructed orientation and dip of the deformation structures (foliation, lineation, and veins) relative to the direction of the stable remanent magnetic vector (see text). Lower hemisphere, equal angle projection. Squares: poles of the planar structures (foliation and veins); closed circles: stretching lineation. A. Upper Structural Domain (Cores 118-735B-1D to 118-735B-36R; Fig. 2). Solid state foliation and lineation. The squares with an oblique line inside correspond to poles of foliations with conjugate dips (see text). The horizontal lineation in the mylonitic shear zone at Core 118-735B-6D (Fig. 2) is identified by its core number. B. Upper Structural Domain; veins. C. Middle Structural Domain (Cores 118-735B-36R to 118735B-56R; Fig. 2); magmatic foliations. D. Middle Structural Domain; solid-state foliations and lineations. The squares with an oblique line inside correspond to the poles of the early, high temperature foliations, parallel to the magmatic foliation of the surrounding gabbros. The foliations and lineations in the shear bands at Cores 118-735B46R and 118-735B-53R to 118-735B-56R (Fig. 2) are identified by their core numbers. E. Middle Structural Domain; veins. F. Lower Structural Domain (Cores 118-735B-56R to 118-735B-88N; Fig. 2); solidstate foliations and lineations. The lower-temperature, higher stress foliation and lineation at Core 118-735B-87R are identified by their core number. G. Lower Structural Domain; veins.

the foliated gabbros, the veins are preferentially perpendicular to the stretching lineation. Most veins shown in Figure $4 \mathrm{~B}$ were measured in the undeformed to moderately deformed intervals between Cores 118-735B-13R and 118-735B-35R (Fig. 2 and Table 1), where the dominant dip direction of the foliation is $\mathrm{V} 220^{\circ}$ to $\mathrm{V} 260^{\circ}$ (Fig. $4 \mathrm{~A}$ and B). The dominant dip of these veins is thus toward $\mathrm{V} 40^{\circ}$ to $\mathrm{V} 80^{\circ}$ (Fig. 4B).

\section{The Middle Structural Domain}

The declination of the SMRV was measured in 36 samples from the Middle Structural Domain (Shipboard Scientific Party, 1989; Pariso et al., this volume). Twenty-one of these samples (Table 1) show a magmatic foliation, or a solid-state ductile foliation and lineation, and/or veins, filled mostly with
A

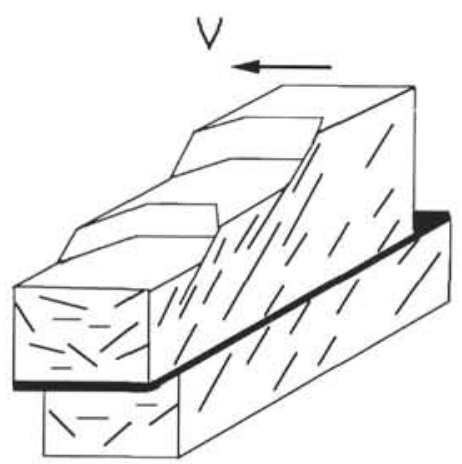

B

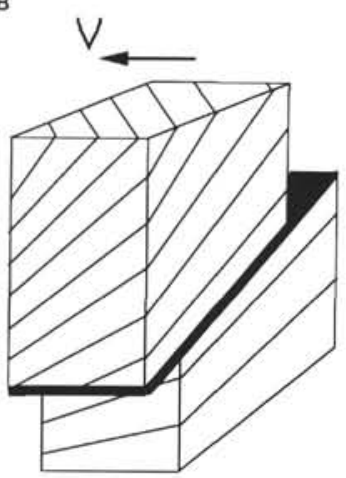

Figure 5. Schematic representation of the foliation data presented in the stereoplots of Figures $4 \mathrm{~A}, 4 \mathrm{C}$ and $4 \mathrm{D}$. V = direction of the remanent magnetic vector. A. Upper Structural Domain; thin discontinuous lines $=$ foliation above and below the subhorizontal shear zone of Core 118-735B-6D (thick line). B. Middle Structural Domain; thin lines = magmatic foliation (note the progressive downward decrease of the dip); thick line $=$ one of the later solid-state shear zones.

plagioclase, clinopyroxene or hornblende (Stakes et al, this volume).

The stereoplots of Figures 4C and 4D show that, as in the Upper Structural Domain, the foliations (magmatic and solidstate) tend to have a northwesterly dip, relative to the SMRV. The dip direction of the magmatic foliation ranges from $\mathrm{V} 280^{\circ}$ to $\mathrm{V} 360^{\circ}$, with a dominant dip toward $\mathrm{V} 320^{\circ}$ (Fig. $4 \mathrm{C}$ ). The dip of this magmatic foliation decreases progressively downward from Core 118-735B-36R to Core 118-735B-56R. This is represented in a schematic way in Figure 5B. In the moderately deformed interval between Cores 118-735B-38R and 118-735B-40R (Fig. 2), the solid-state foliation dips toward $\mathrm{V} 330^{\circ}$ (Fig. 4D), parallel to the magmatic foliation in the neighboring samples (Fig. 4C). This is consistent with the microstructural observations, which suggest that the solidstate episode in this interval resulted from the very last stages of flow in the progressively solidifying magma (Cannat et al., this volume). The foliation and lineation in the meter-thick normal shear zone at Core 118-735B-46R, and in the highly sheared interval between Cores 118-735B-52R and 118-735B56R (Fig. 2), have the same orientation: the dip direction of the foliation is $\mathrm{V} 266^{\circ}$ to $\mathrm{V} 278^{\circ}$, and the lineation is downdip (Fig. 4D). This geometrical similarity is an important constraint on the tectonic evolution of the Site 735 gabbros because the microstructural observations suggest that the deformation at Core 118-735B-46R post-dated the normal shearing at Cores 118-735B-52R to 118-735B-56R and occurred at lower temperatures (Cannat et al., this volume). The sketch in Figure 5B shows the crosscutting relationships between these shear zones and the earlier magmatic foliation of the gabbros. The veins preferentially dip toward $\mathrm{V} 80^{\circ}$ to $\mathrm{V} 140^{\circ}$ (Fig. 4E), roughly perpendicular to the magmatic and solid-state foliations (Figs. 4C and 4D).

\section{The Lower Structural Domain}

The declination of the SRMV was measured in 60 samples from the Lower Structural Domain (Shipboard Scientific Party, 1989; Pariso et al., this volume). Only 19 of these samples (Table 1) show a plastic foliation and lineation, and/or veins, filled mostly with clinopyroxene, or hornblende, and plagioclase (Stakes et al., this volume). This small number of samples reflects the lack of deformation in the upper 20 cores 
(Fig. 2) and the moderate vein density in the Lower Structural Domain (Stakes et al., this volume).

The solid-state plastic foliation, developed in the lower 11 cores (Cores 118-735B-77R to 118-735B-88N; Fig. 2), dips either toward $\mathrm{V} 330^{\circ}$, or toward $\mathrm{V} 260^{\circ}$ to $\mathrm{V} 270^{\circ}$ (Fig. $4 \mathrm{~F}$ ). The lineations are downdip. The two distinct orientations of the foliations do not strictly coincide with distinct tectonic events. However, most amphibolite facies shear zones from Cores $118-735 \mathrm{~B}-85 \mathrm{R}$ to $118-735 \mathrm{~B}-88 \mathrm{~N}$ (Cannat et al., this volume) dip toward $\mathrm{V} 260^{\circ}$ to $\mathrm{V} 270^{\circ}$ (Fig. $4 \mathrm{~F}$ ), while the earlier granulite-facies shear zones in Cores 118-735B-77R to 118-735B$84 \mathrm{R}$ dip dominantly toward $\mathrm{V} 330^{\circ}$, parallel to the magmatic foliation and to some solid-state foliations in the Middle Structural Domain (Figs. 4C and 4D). The veins, measured in deformed and undeformed intervals, dip preferentially toward V95 to $\mathrm{V} 135^{\circ}$ (Fig. 4G) as in the Middle Structural Domain (Fig. 4E).

\section{CONCLUSIONS}

The partial reorientation of the Site 735 deformation structures relative to the SRMV shows that there is a consistent dip direction of the different sets of structures: magmatic foliation; early granulite-facies, solid-state foliation; later, lower-temperature foliation; and veins. This consistency is an a posteriori indication that the in-situ SRMV of each core piece probably did point in the same direction before drilling.

The orientation of the different sets of structures relative to one another suggests that the earliest deformation structures in the Middle and Lower Structural domains (magmatic foliation and early, granulite-facies, solid-state foliation) tend to make a $45^{\circ}$ angle with the later, lower-temperature, shear zones (see sketch in Fig. 5B). This indicates a shift in the principal strain axes orientation during the tectonic evolution of the Site 735 gabbros near the ridge axis.

The dip azimuth of the solid-state foliation is consistently west or northwest (relative to the azimuth of the SRMV). The stretching lineation in a subhorizontal mylonitic shear zone from the Upper Structural Domain trends V290 (Fig. 4A), roughly parallel to the stretching lineation in the main shear zones of the Middle and Lower Structural domains (V260-
V280 ${ }^{\circ}$; Figs. 4D and $4 \mathrm{~F}$ ). This suggests a similar shearing geometry in all these shear zones.

The synkinematic hornblende veins measured in the Upper Structural Domain tend to dip toward the northeast of the SRMV (Fig. 4B), perpendicular to the foliation of the surrounding gabbros (Fig. 4A). In the Middle and Lower Structural domains, the veins' (mostly post-kinematic) dip azimuths are preferentially oriented at $90^{\circ}$ to $140^{\circ}$ from the SRMV (Figs. $4 \mathrm{E}$ and $4 \mathrm{G})$. They are also nearly perpendicular to the magmatic and solid-state foliations measured in these gabbros (Figs. 4D and 4F).

The in-situ azimuth (declination) of the paleomagnetic vector at Site 735 is still undetermined. Once this information becomes available (Pariso, unpubl. data), we will be able to reorient the deformation structures observed in the gabbros in a geographic frame. This will be done by simply rotating the stereoplots in Figure 4 so that the remanent magnetic vector points toward its azimuth relative to geographic North.

\section{ACKNOWLEDGMENTS}

Financial support for this study was provided by ODPFrance and by NSF Grant No. OCE86-9260. One of us (J. P.) also benefited from a JOI/USSAC Fellowship.

\section{REFERENCES}

Dick, H.J.B., Thompson, G., and Bryan, W. B., 1981. Low angle faulting and steady-state emplacement of plutonic rocks at ridge/ transform intersections. EOS (Abstract), 62:406.

Karson, J. A., and Dick, H.J.B., 1984. Deformed and metamorphosed oceanic crust on the Mid-Atlantic Ridge. Ofioliti, 9:279302.

Mével, C., Cannat, M., Gente, P., Marion, E., Auzende, J. M., and Karson, J. A., in press. Emplacement of deep rocks on the west median valley wall of the MARK area (M.A.R., $23^{\circ} \mathrm{N}$ ). Tectonophysics.

Shipboard Scientific Party, 1989. Site 735. In Robinson, P. T., and Von Herzen, R., et al., Proc. ODP, Init. Repts., 118: College Station, TX (Ocean Drilling Program), 89-212.

Date of initial receipt: 24 July 1989

Date of acceptance: 4 June 1990

Ms 118B-162 